\title{
«I kroppsøving så tenker jeg nok mest på det fysiske» - En studie om kroppsøvingslæreres forståelse av helse
}

\author{
Hanne H. Mong \\ Norges idrettshøgskole
}

\begin{abstract}
Sammendrag
Skolen blir i mange sammenhenger pekt på som en arena som bør ta større ansvar for barn og unges helse, og i kroppsøvingsfagsmiljøet diskuteres det i hvilket omfang og hvordan helse skal vektlegges i kroppsøving. Formålet med denne studien er å undersøke hvordan kroppsøvingslærere forstår og underviser om helse på ungdomstrinnet. I den forbindelse er det gjort kvalitative intervjuer med åtte kroppsøvingslærere hvor det er gjennomført tematisk analyse av intervjumaterialet. I dette arbeidet ble det utviklet fire temaer - leerernes forståelse av helse, bevisstgjøre elevene, helse - noe spontant? og leerernes kunnskapsgrunnlag. Analysene viser at lærerens forståelse av helse setter preg på innholdet i undervisningen. Undervisningen knyttet til dette temaet virker som å oppstå spontant og være usystematisk. I og med at lærerne ikke ser ut til å planlegge når og hva de skal undervise om helse, kan det være vanskeligere for elevene å vite når de skal lære om helse i kroppsøvingsfaget.
\end{abstract}

\section{Nøkkelord: Helse; kroppsøving; didaktikk}

\begin{abstract}
"In PE I probably relate it mostly to the physical" - A study of PE teachers comprehension of health

In many contexts schools are presented as an arena that must take more responsibility in raising health awareness in the younger generation. In research on physical education, different scholars discuss how and to what extent physical education should focus on pupil's health. In this study the aim is to investigate how physical education teachers understand and teach health in physical education at secondary schools. For that reason, there has been completed eight qualitative interviews with physical education teachers. In the analyses four themes were developed - teachers understanding of health, make students conscious, health - something spontaneous? Teachers knowledge. The analyses show that the teachers' understanding and knowledge of health influence the content in the teaching. The teaching of health is often not planed for, it happens more spontaneous. Since the teachers do not plan when and how they are going to teach about health, it will be difficult for the students to figure out what and when health is the topic in teaching.
\end{abstract}

\footnotetext{
^Korrespondanse: Hanne H. Mong, epost: hh.mong@nih.no

(C) 2019 H. H. Mong. This is an Open Access article distributed under the terms of the Creative Commons Attribution 4.0 International License (https://creativecommons.org/licenses/by-nc/4.0/), allowing third parties to copy and redistribute the material in any medium or format and to remix, transform, and build upon the material for any purpose, even commercially, provided the original work is properly cited and states its license. 
Keywords: Health; physical education; didactics

Received: November, 2018; Accepted: August, 2019; Published: November, 2019

\section{Bakgrunn}

Helse har vært et aspekt ved kroppsøvingsfaget gjennom lang tid, men det har variert hvordan det har kommet til uttrykk i faget (Augestad, 2003; Kirk, 1992). De senere tiår har likevel flere blitt opptatt av at helse bør få større betydning i faget. Det er basert på diskursen om hvorvidt barn og unges helse blir dårligere, de er for lite i aktivitet og de blir mer stillesittende (Fairclough \& Stratton, 2004; Sallis \& McKenzie, 1991; Steene-Johannessen et al., 2019). Forskere mener at mulighetene som ligger i faget til å arbeide med barn og unges helse ikke utnyttes fullt ut (Fairclough \& Stratton, 2004; McKenzie, Sallis \& Rosengard, 2009; McKenzie, Marshall, Sallis \& Conway, 2000; Sallis \& McKenzie, 1991; Sallis et al., 2012; Tappe \& Burgeson, 2004; Trost, 2004). Samtidig som en del forskere ønsker å gi helse større plass, mener andre at det ikke er hensiktsmessig. Ommundsen (2008) mener at det gir faget en instrumentell dreining som støtter opp om diskursen helsisme (Crawford, 1980). Helsisme tegner et snevert, reduksjonistisk bilde av helse, og innebærer samtidig et moralistisk aspekt. Det moralistiske aspektet bygger på ideen om at fysisk aktivitet gir bedre helse, samt at individet selv har et ansvar for å utvikle egen helse (Colquehoun, 1990; Kirk \& Colquhoun, 1989). Ommundsen (2008) mener at denne tilnærming på kort sikt kan være positivt for å gi relevans, legitimitet og status, men at det vil svekke faget på lang sikt. Det er flere som støtter Ommundsen (2008) i advarslene mot at kroppsøvingsfaget skal legitimeres i en helsediskurs (Dowling, 2010; Evans, Rich, \& Davies, 2004; Kirk, 2006; Quennerstedt, 2008). Advarslene mot en slik legitimering skyldes en skepsis til at faget skal klare å 'fikse' helseutfordringer som allerede har oppstått. Et annet argument er at helse bare er et av flere kunnskapsobjekter elevene skal lære noe om i kroppsøvingsfaget (Ommundsen, 2008). Quennerstedt (2018) mener at i kroppsøvingsfaget bør fokuset endres fra at læring om helse er knyttet til noe individuelt, instrumentelt og dualistisk, til at det blir forstått som et bredere fenomen.

Men hva er helse i kroppsøvingsfaget? Stortingsmelding 22 (Kunnskapsdepartementet, 2011) beskriver kroppsøvingsfaget som et forebyggende tiltak for god folkehelse. Denne stortingsmeldingen bidro til å gi helse et tydeligere fokus i den reviderte læreplanen fra 2012 (Utdanningsdirektoratet, 2012). I utgaven fra 2012 fremheves det i formålet for faget at kroppsøving skal inspirere til en fysisk aktiv livsstil og dermed livslang bevegelsesglede. Faget skal fremme god helse og elevene skal tilegne seg kunnskaper om blant annet helse (Utdanningsdirektoratet, 2012). Læreplanen ble revidert i 2015, men formålet fra 2012 er gjeldende også i dagens læreplan. Et av fagets hovedområder er trening og helse. Hovedområdet omfatter blant annet hvordan ulike aktiviteter kan påvirke den enkeltes helse. Sammenhengen mellom fysisk aktivitet og livsstil skal være sentralt i faget, men baseres på den enkeltes interesser og mestring. Elevenes kunnskaper, erfaringer og egne refleksjoner om ulike aktivitetsformer 


\section{H. H. Mong}

må også bli vektlagt hvis hensikten er at kroppsøvingsfaget skal kunne være grunnlag for en aktiv livsstil. I tillegg er helse også tydeliggjort gjennom flere kompetansemål på ungdomstrinnet: «bruke leik og ulike treningsformer for å utvikle eigen kropp og helse, forklare samanhengen mellom fysisk aktivitet og helse, og forklare korleis ulike kroppsideal og ulik rørslekultur påverkar trening, ernæring, livsstil og helse» (Utdanningsdirektoratet, 2015, s. 5). Disse kompetanseområdene viser at helse er en sentral del av kroppsøvingsfaget, og skal dermed vektlegges i undervisningen. Selv om helse kommer tydelig til uttrykk i fagets læreplan viser tidligere forskning (Alfrey, Cale \& Harris, 2012; Armour \& Harris, 2013) at kroppsøvingslærere har en begrenset forståelse av helse som fenomen. Dette preger undervisningen knyttet til tematikken (Alfrey, Cale \& Webb, 2012). Samtidig kan vi stille spørsmål om hva elevene lærer om helse, og hvordan undervisningen foregår. Hvordan arbeider lærerne med det som står i læreplanen? Hvilke didaktiske grep gjør kroppsøvingslærerne for at elevene skal lære om helse? Da forskning viser at ulik forståelse av helse kan gi ulik undervisning om temaet (Armour \& Harris, 2013; Mong \& Standal, 2019; Quennerstedt, 2008) er hensikten med denne studien å undersøke både hvordan kroppsøvingslærere forstår helse og hvordan de underviser om helse. Problemstillingen for studien er; hvordan forstår kroppsøvingslcerere helse $i$ tilknytning til undervisning?

\section{Teoretisk perspektiv på helse}

I denne delen vil ulike teoretiske perspektiv på helse bli presentert, og senere vil de bli benyttet for å belyse lærernes forståelse av helse. Verdens helseorganisasjon har utviklet en definisjon på helse: «helse er en tilstand av fullstendig fysisk, mental og sosialt velvære og ikke bare fravær av sykdom og lyte» (Verdens helseorganisasjon (WHO), 1946, s. 1). Definisjonen har fått kritikk for å være utopisk og vanskelig å oppnå (Huber et al., 2011; Larson, 1999; Mæland, 2009), for når har individet fullstendig fysisk, psykisk og sosialt velvære? Samtidig er definisjonen velkjent og de ulike komponentene ved helse - fysisk, psykisk og sosial - trekkes frem.

Christopher Boorse (1977) har arbeidet for å gi et begrunnet svar på hva helse er gjennom en biomedisinsk forståelse. Boorse (1977) poengterer at helse handler om normal fungering, hvor normalitet og funksjon vurderes ut fra en statistisk norm. Han legger særlig vekt på normale biologiske funksjoner. Kroppens deler har ulike funksjoner som alle er målrettet. Videre trekker han frem at hvis organismen ikke er rammet av sykdom, er det en sunn og frisk organisme. Med andre ord definerer Boorse (1977) helse som fravær av sykdom. Han trekker også frem positiv helse. Positiv helse er relatert til forebygging av sykdom, og et eksempel kan være at fysisk aktivitet og bevegelse kan forebygge sykdommer (Boorse, 1977). Fysisk aktivitet kan dermed være positivt for individets helse og dermed gjøre avstanden til sykdom større. Boorse har imidlertid fått kritikk for å ikke være opptatt av helse, men av ulike risikoer som sykdom, skader, funksjonsnedsettelser eller andre defekter (Svenaeus, 2013). Boorse har flere ganger prøvd å svare på kritikken (Boorse, 1997, 2014), men holder fast på at helse handler om fravær av sykdom (Boorse, 1997). 
En annen måte å forstå helse på blir presentert gjennom en salutogenisk tilnærming til helse. I motsetning til det biomedisinske perspektivet, som er opptatt av sykdom, er fokuset i en salutogen tilnærming et helhetlig syn på helse (Quennerstedt, 2006). Ved en salutogen tilnærming er ikke helse noe man har eller ikke har. Derimot skapes og opprettholdes ulike grader av helse gjennom en prosess (Antonovsky, 1979), der helse blir forstått som et kontinuum hvor individet befinner seg til enhver tid. For å forstå hvorfor og hvordan individer beveger seg på kontinuumet, er individets opplevelse av sammenheng (OAS) sentralt. Fokuset i en salutogenisk tilnærming er dermed ikke å forklare hvordan individer oppnår helse, men å forstå individets OAS og generelle motstandsressurser (Antonovsky, 1979, 1996).

\section{Metode}

Denne studien er del av et forskningsprosjekt, Helse - et didaktisk fenomen $i$ kroppsøvingsfaget, på trinn 8-10 i grunnskolen. Lærerne som deltar i studien er strategisk utvalgt, basert på ulike kriterier. Kriterier for rekruttering var variasjon i deltakernes alder, kjønn, arbeidserfaring, og at de hadde formell kompetanse i kroppsøving (se tabell 1). For å rekruttere deltakere til studien ble prosjektet først presentert for 20 praksislærere ved forskers institusjon. Av disse ønsket to lærere å delta, og ble dermed rekruttert. Da det var ønskelig med flere lærere, ble det sendt informasjon om studien til 45 skoler fra ulike deler av landet. Rektor på de ulike skolene videreformidlet e-posten til kroppsøvingslærerne. De som ønsket å delta i studien ble bedt om å besvare e-posten, og seks menn og to kvinner i alderen 26-49 år sa seg villig til å bli intervjuet. Tabell 1 gir en oversikt over lærerne som deltar, og de er gitt fiktive navn. Tabellen viser også at Sverre ikke har studiepoeng i kroppsøving. Vedkommende underviser basert på realkompetanse, og denne informasjonen ble kjent underveis $\mathrm{i}$ intervjuet. Intervjuet ble fullført, men siden svarene til Sverre ikke skiller seg nevneverdig fra de andre intervjuene ble det inkludert $\mathrm{i}$ analysene.

Tabell 1. Oversikt over deltakere.

\begin{tabular}{|l|l|l|l|}
\hline Deltakere & Alder & Antall år i læreryrket & Utdanning \\
\hline Mats & 36 & 10 & Master idrett + Praktisk Pedagogisk Utdanning (PPU) \\
\hline Jarle & 29 & 4 & Allmennlærer m. kroppsøving \\
\hline Marie & 49 & 25 & Allmennlærer m. kroppsøving \\
\hline Sverre & 35 & 10 & Allmennlærer u. kroppsøving \\
\hline Stian & 26 & 3 måneder & Bachelor idrett + PPU \\
\hline Martin & 26 & 3 måneder & Grunnskolelærer + master i idrett/kroppsøving \\
\hline Tore & 34 & 10 & Faglærer kroppsøving \\
\hline Ingrid & 28 & 1 & Faglærer + master kroppsøving \\
\hline
\end{tabular}

Intervjuene hadde en semi-strukturert tilnærming (Brinkmann \& Tanggaard, 2012). Det ble brukt en intervjuguide som hadde noen sentrale temaer og spørsmål, men intervjuene tok ulik form etter hva deltakerne brakte frem. Intervjuguiden inneholdt 
spørsmål knyttet til lærernes forståelse av helse, hvordan de tolker og arbeider med læreplanen, samt hvordan de underviser om helse. Lengden på intervjuene varierte fra 40-75 minutter. Intervjuene ble tatt opp på lydbånd og deretter transkribert.

I analysearbeidet ble det utført tematisk analyse, og MaXQda ${ }^{1}$ ble brukt som hjelpemiddel i arbeidet. Analysen av det transkriberte materialet baserer seg på Braun, Clarke og Weate (2016) sin sekstrinnsmodell for tematisk analyse. Fase 1-2 omtales som bli kjent fasen og koding. I fase 1 ble intervjuene først lest i sin helhet, før de gradvis ble lest grundigere. I fase 2 startet kodingen og disse ble utviklet for å tydeliggjøre innholdet i intervjuet. Fase 3-5 er temautvikling, forbedring og navngiving. I disse fasene var arbeidet fokusert på å utvikle kodene til temaer, forbedre disse og gi temaene gode navn. I første omgang var temaene som ble utviklet generelle og vide. Eksempler på temaer var da lcerernes helseforståelse og undervisning om helse. Etterhvert ble temaene mer spesifikke, noe som eksemplifiseres gjennom at temaet undervisning om helse har blitt delt opp i temaene bevisstgjøre elevene og helse-noe spontant. I arbeidet med å bryte ned disse overordnede temaene har det også kommet frem flere temaer. Arbeidet med å navngi temaene har blitt utført og redigert over tid for å få frem nyansene i temaene. Den 6. og avsluttende fasen er skrivefasen. Braun og Clarke (2006) påpeker samtidig at denne modellen ikke kan følges slavisk og prosessen foregår over tid. På samme måte er ikke analyseprosessen statisk, men en kombinasjon av aktive valg forsker tar (Braun, Clarke \& Weate, 2016). I denne studien er det blitt utført både induktive og deduktive tolkninger. Ved induktive tolkinger tas det utgangspunkt i datamaterialet (induktiv), mens deduktive tolkninger finner større støtte i relevant teori (deduktiv) (Braun \& Clarke, 2006). I denne studien ble det først gjort induktive tolkninger av datamaterialet. Etterpå ble det gjort deduktive tolkninger hvor relevant teori ble benyttet for å belyse og støtte opp om de induktive tolkningene (Braun \& Clarke, 2006; Braun, Clarke \& Weate, 2016). Et eksempel er temaet larernes forståelse av helse. Temaet ble først utviklet induktiv, der fokuset var å få innblikk i hva og hvordan lærerne pratet om helse. Deretter ble lærernes utsagn sett i lys av relevant teori for å analysere hvordan det kunne kobles til ulike teoretiske perspektiver på helse. Temaene som er utviklet har både et semantisk og latent fokus (Braun, Clarke \& Weate, 2016). Det betyr at noen temaer tar direkte utgangspunkt i hva deltakerne sier. Andre går mer i dybden for å få frem hva deltakerne mener med det de sier.

Studien er godkjent av både $\mathrm{NSD}^{2}$ og etisk komite ved ansvarlig institusjon. Samtykke er blitt innhentet fra alle deltakerne, de er anonymisert og gitt fiktive navn.

\section{Funn}

Gjennom analysene er det utviklet fire temaer. Temaene er;

- Lærernes forståelse av helse

- Bevisstgjøre elevene

\footnotetext{
${ }^{1}$ www.MaXQda.com

${ }^{2}$ Norsk senter for forskningsdata (www.nsd.uib.no).
} 
- Helse - noe spontant?

- Lærernes kunnskapsgrunnlag

Temaene vil i denne delen bli presentert grundigere.

\section{Lærernes forståelse av helse}

Lærerne ble i intervjuet spurt om hva de tenker på når de hører ordet helse. Deltakerne uttrykker at det er utfordrende å definere helse, fordi det er et sammensatt begrep. Martin forteller: «... jeg tenker kanskje at det er litt sammensatt ... du har på en måte ... hvordan kroppen din er, den fysiske biten av det og så tenker jeg på kosthold og så tenker jeg også litt sånn psykisk helse». Martin skiller altså mellom fysisk og psykisk helse. Stian forteller; «jeg tenker jo at det går på fysisk helse, men også psykisk og sosialt». Stian bruker dermed tredelingen fysisk, psykisk og sosial helse som også brukes i definisjonen til Verdens helseorganisasjon (1946).

Samlet sett viser analysene av materialet at lærerne forstår helse som å handle om å ha det bra, å mestre livet og å ha det godt med seg selv. Tore forklarer: « ... tenker både fysisk og psykisk, bare at man har det greit ... Hvis alle hadde hatt det bra fysisk og psykisk så tror jeg ikke vi hadde hatt så mange problemer igjen». Det ble også pratet om hva de tenkte at helse er i kroppsøvingsfaget. Marie svarer da; «jeg tenker det er hverdagslivsmestring, den fysiske og psykiske delen av å klare livet sitt».

\section{Bevisstgjøre elevene}

I intervjuene kommer det frem at lærerne er spesielt opptatt av å bevisstgjøre elevene. Særlig er de opptatt av å bevisstgjøre elevene på viktigheten av fysisk aktivitet i hverdagen, hvordan de kan ta vare på egen kropp, samt enkle treningsprinsipper:

For min del så tenker jeg at det handler om å bevisstgjøre de litt på hva de kan giøre for å utvikle egen form ... så det handler jo mer om ... ehh ... om å være litt bevisst på hvordan kroppen er, hvordan din egen kropp fungerer og hvordan du kan forbedre den eller forverre den. (Sverre)

Da lærerne ble spurt om hvordan de arbeider med å bevisstgjøre elevene, var det utfordrende for flere å konkretisere hva de giør. Det går igjen at lærerne gir små drypp til elevene, som for eksempel Marie sier: «... det jeg prøver å få inn om helse til elever, det prøver jeg å ta sånn i små bolker muntlig når vi skal starte opp for eksempel ...». Disse små dryppene kommer enten i oppstart eller avslutningen av timen og inneholder vanligvis informasjon om helsegevinster ved fysisk aktivitet. Sverre forteller at de teoretiske dryppene ofte gir tilleggsinformasion til det de giør i timene: «med små, sånn teoretiske drypp, sånn hvorfor giør vi det, hvorfor er dette viktig ... så litt den der biten der tenker jeg at jeg prøver å få inn».

\section{Helse - noe spontant?}

Alle lærerne omtaler helse som noe elevene får ved å være i aktivitet: «Jeg tror vi lærere har det med oss når vi planlegger ting, at vi har en intensjon om at det skal 
fremme helse på kort eller lang sikt. Men jeg tror ikke elevene tenker over det» (Tore).

Selv om lærerne har helse som tema i bakhodet, er det mer tilfeldig hvordan de tilrettelegger undervisningen. Nesten alle lærerne formidler at helse ikke er eksplisitt nevnt $i$ årsplaner, fordi planene tar utgangspunkt i aktiviteter og ikke tematikker. Jarle sier; «Fordi det vi kanskje giør i kroppsøving er at vi knytter helse mot ... aktiviteten vi driver med da. At når vi er i aktiviteten så kan vi si at dette er helsebringende resten av livet ditt ...». I dette sitatet ser vi at Jarle formidler dette muntlig til elevene samtidig som han er usikker på om dette gjøres systematisk og tydelig for elevene.

Analysene tyder på at lærerne er usikre på hvor mye elevene lærer om helse gjennom undervisningen. I intervjuene ble lærerne spurt om hva de trodde elevene ville si at de hadde lært om helse gjennom kroppsøvingsfaget. De fleste sa at de trodde elevene ville svart «ingenting». Lærerne oppfatter at elevene får med seg aktiviteten som står på planen og ikke den undervisningen lærerne trekker inn underveis i timene. Marie forklarer det slik;

Fordi at jeg tror ikke de oppfatter at det er det [helse] vi har som tema. For jeg tror de oppfatter det som om at vi har, nå har vi fotball, nå har vi ehh ... utholdenhet og styrke ikke sant, de oppfatter det som at nå er det volleyball og nå er det ... De opplever de tingene som står på planen, de opplever ikke de tingene som vi fletter inn imellom. (Marie)

Selv om hovedinntrykket fra analysene er at lærerne ikke eksplisitt tematiserer helse i undervisningen, men gir det gjennom små drypp, finnes det også eksempler på det motsatte. Ingrid forteller at på hennes skole har helse blitt et eget tema på årsplanen fra og med det skoleåret intervjuet ble gjennomført. Der er de opptatt av å ha karaktergrunnlag på alle kompetansemål. For å forsikre seg at de hadde karaktergrunnlag også på de kompetansemål som omhandler helse, ble temaet satt på årsplanen.

\section{Lærernes kunnskapsgrunnlag}

Dette temaet handler om hvilken kunnskap lærerne sier de har, eller ikke har, til å undervise i emner relatert til de kompetansemål i læreplanen som omhandler helse. I analysene ble det tydelig at flere av lærerne opplever at de er kompetente til å undervise om trening og fysiologi. Samtidig opplever de det mer utfordrende å arbeide med det læreplanen sier om kroppsidealer og psykisk helse. Lærerne opplever at det er utfordrende å giøre det til en del av undervisningen, da det er vanskelig å bryte ned og "vanskelig å angripe» (Mats). I tillegg er det vanskelig å undervise om kroppsideal slik at det passer alle elevene. Både Mats og Tore opplever det som et krevende tema å undervise. I tillegg kan det også være et sårbart tema for flere elever. Elevenes evne til å håndtere et sårbart tema vil også være svært ulikt. Tore uttrykker det som krevende ved at: «du har 30 stykker foran deg som du kanskje burde snakket til på 30 forskjellige måter om akkurat dette temaet her».

Gjennom analysene ble det også tydelig at lærerne ikke ønsker teoriundervisning i kroppsøving. Likevel virket det som om lærerne har en forståelse for at noen ting må 
undervises teoretisk: «Så ... teoretisk så er det ikke så vanskelig å jobbe med [psykisk helse], men det er mer det å faktisk få gjennomført det som kanskje er litt vanskelig» (Martin). Utsagnet til Martin tolker jeg til at det ikke er vanskelig å undervise om psykisk helse teoretisk, men at det ikke er i tråd med hvordan han ønsker å undervise i kroppsøving. Han sier også at det hadde vært enklere å undervise om psykisk helse gjennom teoretisk undervisning. Martin og flere av de andre lærerne gir uttrykk for at kompetansemålene som omhandler helse må undervises teoretisk, men at dette er noe de vegrer seg for: "Jeg er jo faktisk veldig opptatt av at dette faget skal være et fag der elevene faktisk er i aktivitet også, at det ikke blir et pratefag eller teorifag» (Mats). Oppfatningen av at noen kompetansemål må arbeides med teoretisk virker til å være en utfordring for lærerne. Siden lærerne ikke ønsker teoriundervisning i faget får kompetansemålene om helse lite fokus og havner fort i glemmeboken. Jarle sier i sitt intervju at helse ikke er noe han arbeider mye med;

Og når du har sagt det, jeg vet ikke bare en følelse som kom i meg nå, som ikke er helt bra. OK, check akkurat på det målet. Da har du liksom checket det ut, du har ikke gitt de noen kompetanse, men du har sagt det. Og det er jo det som er skremmende at vi giør det.

I forkant av dette sitatet forteller Jarle at kompetansemålet som omhandler sammenhengen mellom fysisk aktivitet og helse er noe han av og til setter sammen med andre kompetansemål for å kunne sjekke det ut, med andre ord, for å kunne si at de har jobbet med det. Flere av lærerne uttrykker seg på lignende måter; helse er et tema de ikke arbeider nok med, og at det bør tydeliggjøres i undervisningen. Noen uttrykker også at det gir dem dårlig samvittighet.

\section{Diskusjon}

Bakgrunnen for denne studien var å få kjennskap til hvordan et utvalg kroppsøvingslærere forstår helse og hvordan de underviser om temaet i faget. Gjennom analysene ble det tydelig at lærerne forstår helse som et sammensatt fenomen, og at det i tillegg er vanskelig å definere. Det ser ut til at lærerne i liten grad baserer sin forståelse av helse på et teoretisk perspektiv. Det er likevel gjenkjennbare elementer fra både biomedisinske og salutogeniske forståelser om helse i lærernes tanker og refleksjoner. Måten lærerne prater om helse på følger ikke Boorse (1977) sin forståelse om at helse handler om fravær av sykdom. Lærerne støtter likevel Boorse sin tanke om at for å utvikle god helse er det positivt å forebygge for risikofaktorer og sykdom (1997). Måten lærerne prater om helse på synes heller ikke å følge en salutogenisk forståelse av helse. Likevel er de opptatt av at helse er noe som varierer etter hvordan individet har det, og at helse ikke er noe statisk. I tillegg er de opptatt av at elevene skal lære hvordan de kan håndtere og møte ulike utfordringer. Dette viser at det er noen likheter til en salutogenisk forståelse. Videre tar flere av lærerne utgangspunkt i Verdens helseorganisasjon (1946) sin definisjon og inndelingen i fysisk, psykisk og sosial helse. Definisjonen presenterer ulike aspekter ved fenomenet, men vektlegger at alle tre må 
være tilstede for å skape en helhetlig forståelse av helse. Når lærerne prater om helse skaper de imidlertid tydelige skiller mellom aspektene, og begrepet deles opp og mister dermed helheten. Gjennom intervjuene kan det virke som om lærerne i hovedsak baserer sin forståelse av helse på hverdagslige begrunnelser, ikke teoretiske. Siden de bare nevner WHOs definisjon på helse og ingen andre teoretiske perspektiver, kan vi stille spørsmål ved om de kjenner til andre teoretiske forståelser?

I intervjuene kommer det også frem at helse er et tema lærerne ikke arbeider systematisk med i undervisningen. I tillegg er det ikke alle som tydeliggjør tematikken for elevene. Redelius, Quennerstedt og Öhman (2015) mener at å uttrykke målene for undervisningen hjelper elevene å forstå hva undervisningen handler om. Analysene i denne studien viser at lærerne på en side er opptatt av viktigheten av å tydeliggjøre undervisningens mål for elevene. Flere av lærerne forteller at det å skape tydelige læringsmål er noe de har jobbet spesielt med i faget. På den andre siden forteller lærerne at helse ikke er et eget tema på årsplanene, og at de i liten grad har læringsmål som går på helse. At elevene får kjennskap til undervisningens hensikt og læringsmål blir spesielt viktig hvis fokuset skal være å lære noe om helse, og ikke bare være aktiviteter som kan bidra til å utvikle egen helse.

I tråd med tidligere forskning (Cale, Harris, \& Chen, 2014; Webb, Quennerstedt, \& Öhman, 2008) viser funn fra denne studien at lærerne bare tar med seg deler av egen forståelse om helse inn i undervisningen. I intervjuene ble det tydelig at lærerne vektlegger fysisk helse og fysisk aktivitet. Det er forståelig i og med at det er det fysiske aspektet ved helse de gir inntrykk av å ha best kunnskap om. Forskning viser at kroppsøving er et tradisjonsbundet fag der fagets etablerte praksiser og utfordringer ser ut til å gå igjen (Moen, 2011; Moen, Westlie, Bjørke \& Brattli, 2018). I tillegg blir fysisk aktivitet i stor grad vektlagt i undervisningen, noe som trolig kan relateres til fagets aktivitetsdiskurs (Kirk, 2010). Det å ta i bruk andre arbeidsmåter i faget kan være en måte å dempe aktivitetsfokuset, og dermed åpne opp for at elevene får kjennskap til flere aspekter ved helse enn bare det fysiske (Quennerstedt, 2019). Det kan gjøres gjennom å introdusere lærerne for andre undervisningsmetoder og å utfordre dem på å planlegge timer der fysisk aktivitet ikke er hovedfokuset. Quennerstedt (2018) er opptatt av at en salutogenisk tilnærming til helse kan tilby kroppsøvingsfaget en bredere forståelse og flere aspekter ved helse enn det den biomedisinske tilnærmingen tilbyr faget. En måte å gjøre det på er å stille salutogeniske spørsmål. For eksempel « hvordan kan fysisk aktivitet eller bevegelse bidra til å utvikle ressurser som fasiliterer elevenes helseutvikling?» (Quennerstedt, 2008, s. 277). Slike spørsmål viser at en salutogenisk tilnærming til helse i kroppsøvingsfaget ikke bare handler om kunnskap om helse på en instrumentell måte, men om å ha fokus på elevenes fysiologiske, psykologiske og sosiale ressurser (Quennerstedt, 2008).

I denne studien er ikke elevene intervjuet og derfor er det vanskelig å si noe om hvordan elevene opplever undervisningen knyttet til helse. I intervjuene blir det tydelig at lærerne er opptatt av at innholdet i undervisningen skal bevisstgjøre elevene på helse med fokus på de fysiske aspektene. På samme måte som Cardon, Haerens, 
Verstraete og de Bourdeaudhuij (2009) i sin studie er opptatt av å skape en kognitiv atferdsendring hos ungdommene, er lærerne opptatt av at elevene skal erverve seg ny kunnskap som kan føre til en atferdsendring hvor fysisk aktivitet blir en større del av hverdagen deres. Et spørsmål blir da hvordan lærerne forventer at elevene skal tilegne seg denne kunnskapen når lærerne underviser om helse gjennom små drypp? I den offentlige utredningen Fremtidens skole: Fornyelser av fag og kompetanser (NOU, 2015: 8), vektlegger utvalget begrepet dybdelæring. Dybdelæring handler om at elevene blir i stand til å håndtere kompleks informasjon og vurderer denne informasjonen kritisk. Dette forutsetter aktiv deltakelse i egne læringsprosesser, bruk av læringsstrategier og evne til å vurdere egen mestring og fremgang (NOU, 2015: 8). Å lære om helse i kroppsøving blir derfor noe annet enn å bli introdusert til ulike former for trening og informert om helsegevinster. Elevene bør få kompetanse som giør dem i stand til å kunne, som dagens læreplan sier, vurdere ulike kroppsideal og bevegelseskulturer. I tillegg blir det også viktig at undervisningen ikke bare handler om mye fysisk aktivitet, men at elevene får muligheter til å verdsette å være i bevegelse (Haerens, Kirk, Cardon \& De Bourdeaudhuij, 2011; Siedentop, 1996). Det er også usikkert om det lærerne beskriver som små drypp vil bidra til å skape dybdelæring hos elevene.

\section{Konklusjon}

Problemstillingen i denne studien er; hvordan forstår lærere helse i tilknytning til undervisning? For å besvare problemstillingen er det i denne kvalitative studien blitt utført intervju med 8 kroppsøvingslærere. Funn fra studien viser at lærerne forstår helse på ulike måter. Flere av lærerne sier at helse er et sammensatt fenomen og de støtter seg til Verdens helseorganisasjon sin inndeling i fysisk, psykisk og sosial helse (1946). I undervisningen ser det imidlertid ut til at lærerne hovedsakelig vektlegger et av aspektene - fysisk helse. Ved å bare fokusere på dette aspektet introduserer de elevene for en snever forståelse av helse som ikke er i tråd med hvordan lærerne selv forstår fenomenet. Å inkludere flere aspekter av helse i undervisningen vil kunne gi elevene større muligheter til å forstå helse som noe mer enn fysisk helse. For å kunne gjøre det, bør temaet helse løftes opp og arbeides med slik at det ikke bare er noe som skjer spontant. Det kan gjøres gjennom å planlegge undervisningen utfra temaer, og ikke ved å ta utgangspunkt i aktiviteter. Det vil også kunne være hensiktsmessig å utvikle læringsmål knyttet til helse på samme måte som lærerne sier de utvikler læringsmål $\mathrm{i}$ andre temaer.

Studien viser at lærerne mangler kunnskap om hvordan de kan undervise helse i tråd med egen forståelse og læreplanen. Derfor er det viktig med videre forskning på fagfeltet. Funn fra denne studien viser at det trengs mer kunnskap om hvordan helse undervises i lærerutdanningene. Det vil være relevant å undersøke hvordan lærerutdanningen arbeider med å introdusere lærerne for helsebegrepet og hvordan det arbeides med å gjøre lærerne kjent med det læreplanen forteller om helse. 


\section{H. H. Mong}

\section{Kilder}

Alfrey, L., Cale, L., \& Webb, L. A. (2012). Physical education teachers' continuing professional development in health-related exercise. Physical Education and Sport Pedagogy, 17(5), 477-491. doi: 10.1080/17408989. 2011.594429

Antonovsky, A. (1979). Health, Stress, and Coping. San Francisco: Jossey-Bass San Francisco.

Antonovsky, A. (1996). The salutogenic model as a theory to guide health promotion. Health Promotion International, 11(1), 11-18.

Armour, K., \& Harris, J. (2013). Making the Case for Developing New PE-for-Health Pedagogies. Quest, 65(2), 201-219. doi: 10.1080/00336297.2013.773531

Augestad, P. (2003). Skolering av kroppen: om kunnskap og makt i kroppsøvingsfaget. Bø: Høgskolen i Telemark, Avdeling for allmenne fag, Institutt for idretts- og friluftslivsfag.

Boorse, C. (1977). Health as a theoretical concept. Philosophy of science, 44(4), 542-573.

Boorse, C. (1997). A rebuttal on health. I J. Humber \& R. Almeder (Red.), What is disease (s. 1-134). New York: Springer. Hentet fra https://link.springer.com/chapter/10.1007/978-1-59259-451-1_1

Boorse, C. (2014). A second rebuttal on health. Fournal of Medicine and Philosophy, 39(6), 683-724. doi: $10.1093 / \mathrm{jmp} / \mathrm{jhu} 035$

Braun, V., Clarke, V., \& Weate, P. (2016). Using thematic analysis in sport and exercise research. I B. Smith (Red.), Routledge Handbook of Qualitiative Reseach in Sport and Exercise. New York: Routledge.

Braun, V., \& Clarke, V. (2006). Using thematic analysis in psychology. Qualitative research in psychology, 3(2), 77-101. doi: https://doi.org/10.1191/1478088706qp063oa

Brinkmann, S., \& Tanggaard, L. (2012). Kvalitative metoder: empiri og teoriutvikling. Oslo: Gyldendal akademisk.

Cale, L., Harris, J., \& Chen, M. H. (2014). Monitoring health, activity and fitness in physical education: its current and future state of health. Sport, Education and Society, 19(4), 376-397. doi:10.1080/13573322. 2012.681298

Cardon, G. M., Haerens, L. L., Verstraete, S., \& de Bourdeaudhuij, I. (2009). Perceptions of a School-Based Self-Management Program Promoting an Active Lifestyle Among Elementary Schoolchildren, Teachers, and Parents. Fournal of Teaching in Physical Education, 28(2), 141-154.

Colquehoun, D. (1990). Images of healthism in Health-based physical education. I R.Tinning, D. Kirk, (Red.). Physical education, curriculum, and culture: critical issues in contempary crisis (s. 225-251). London: Falmer Press.

Crawford, R. (1980). Healthism and the medicalization of everyday life. International journal of health services, 10(3), 365-388.

Dowling, F. (2010). Fysisk aktivitet og god helse i kroppsøvingsfaget: problematisk, ikke automatisk. I K. Steinsholt. (Red.), Aktive liv, (s. 205-218). Trondheim: Tapir akademisk.

Evans, J., Rich, E., \& Davies, B. (2004). The emperor's new clothes: fat, thin, and overweight. The social fabrication of risk and ill health. Fournal of Teaching in Physical Education, 23, 372-391.

Fairclough, S., \& Stratton, G. (2004). 'Physical education makes you fit and healthy'. Physical education's contribution to young people's physical activity levels. Health education research, 20(1), 14-23. https://doi. org/10.1093/her/cyg101

Haerens, L., Kirk, D., Cardon, G., \& De Bourdeaudhuij, I. (2011). Toward the development of a pedagogical model for health-based physical education. Quest, 63(3), 321-338.

Huber, M., Knottnerus, J. A., Green, L., van der Horst, H., Jadad, A. R., Kromhout, D., ... van der Meer, J. W. M. (2011). How should we define health. Bmj, 343, 1-3. doi: 10.1136/bmj.d4163

Kirk, D. (1992). Health, Fitness and the Rise of Scientific Functionalism. I D. Kirk (Red.), Defining Physical Education, (s. 125-155). London: Routledge.

Kirk, D. (2006). The 'obesity crisis' and school physical education. Sport, Education and Society, 11(2), $121-133$.

Kirk, D. (2010). Physical Education Futures. London: Routledge.

Kirk, D., \& Colquhoun, D. (1989). Healthism and Physical Education. British fournal of Sociology of Education, 10(4), 417-434. doi: 10.1080/0142569890100403

Kunnskapsdepartementet (2011). Motivasjon-Mestring-Muligheter. (Meld.St. 22, 2011) Hentet fra https://www. regjeringen.no/no/dokumenter/meld-st-22-2010--2011/id641251/

Larson, J. S. (1999). The conceptualization of health. Medical Care Research and Review, 56(2), $123-136$.

Mæland, J. G. (2009). Hva er HELSE. Oslo: Universitetsforlaget.

McKenzie, T. L., Marshall, S. J., Sallis, J. F., \& Conway, T. L. (2000). Student activity levels, lesson context, and teacher behavior during middle school physical education. Research Quarterly for Exercise and Sport, 71(3), 249-259. 


\section{«I kroppsøving så tenker jeg nok mest på det fysiske»}

McKenzie, T. L., Sallis, J. F., \& Rosengard, P. (2009). Beyond the Stucco Tower: Design, Development, and Dissemination of the SPARK Physical Education Programs. Quest, 61(1), 114-127.

Moen, K. M. (2011). "Shaking or stirring"?: a case-study of physical education teacher education in Norway. (Doktorgradsavhandling) Norwegian School of Sport Sciences, Oslo

Moen, K. M., Westlie, K., Bjørke, L., \& Brattli, V. H. (2018). Når ambisjon møter tradisjon: En nasjonal kartleggingsstudie av kroppsøvingsfaget $i$ grunnskolen (5.-10. trinn), Høgskolen i Innlandet. Hentet fra https://brage.inn.no/inn-xmlui/bitstream/handle/11250/2482450/opprapp01_18_online.pdf?sequence= 1 \&isAllowed $=\mathrm{y}$

Mong, H. H., \& Standal, Ø. F. (2019). Didactics of health in physical education. Physical Education and Sport Pedagogy, 24(5), 506-518.

NOU 2015:8. (2018) Fremtidens skole. Fornyelse av fag og kompetanser, Oslo: Kunnskapsdepartementet. Hentet 29.10.2018 fra https:/www.regjeringen.no/no/dokumenter/nou-2015-8/id2417001/

Ommundsen, Y. (2008). Kroppsøving: Danning eller helse? Om to ulike begrunnelser for faget og deres konsekvenser. I P. Arneberg \& L. G. Briseid. (Red.),. Fag og danning - mellom individ og fellesskap (s. 193-208). Bergen: Fagbokforlaget.

Quennerstedt, M. (2006). Att lära sig hälsa. (Doktorgradsavhandling). Örebro universitetsbibliotek, Ôrebro.

Quennerstedt, M. (2008). Exploring the relation between physical activity and health - a salutogenic approach to physical education. Sport, Education and Society, 13(3), 267-283.

Quennerstedt, M. (2018). Healthying physical education-on the possibility of learning health. Physical Education and Sport Pedagogy, 24(1), 1-15. https://doi.org/10.1080/17408989.2018.1539705

Quennerstedt, M. (2019). Physical education and the art of teaching: transformative learning and teaching in physical education and sports pedagogy. Sport Education and Society. 25(6), 611-623 doi:https://doi.org/ $10.1080 / 13573322.2019 .1574731$

Redelius, K., Quennerstedt, M., \& Öhman, M. (2015). Communicating aims and learning goals in physical education: part of a subject for learning? Sport, Education $\mathcal{F}$ Society, 20(5), 641-655.

Sallis, J. F., \& McKenzie, T. L. (1991). Physical education's role in public health. Research Quarterly for Exercise and Sport, 62(2), 124-137.

Sallis, J. F., McKenzie, T. L., Beets, M.W., Beighle, A., Erwin, H., \& Lee, S. (2012). Physical education's role in public health: Steps forward and backward over 20 years and HOPE for the future. Research Quarterly for Exercise and Sport, 83(2), 125-135.

Siedentop, D. (1996). Valuing the physically active life: Contemporary and future directions. Quest, 48(3), $266-274$.

Steene-Johannessen, J., Anderssen, S. A., Bratteteig, M., Dalhaug, E. M., Andersen, I. D., Andersen, O. K., ... Dalene, K. E. (2019). Nasjonalt overvåkingssystem for fysisk aktivitet og fysisk form. Hentet fra https://fhi.no/ globalassets/bilder/rapporter-og-trykksaker/2019/ungkan3_rapport_final_27.02.19.pdf

Svenaeus, F. (2013). The Hermeneutics of Medicine and the Phenomenology of Health: Steps Towards a Philosophy of Medical Practice (5). London: Kluwer Academic Publishers.

Tappe, M. K., \& Burgeson, C. R. (2004). Physical Education: A Cornerstone for Physically Active Lifestyles. Fournal of Teaching in Physical Education, 23(4), 281-299.

Trost, S. G. (2004). School physical education in the post-report era: An analysis from public health. Fournal of Teaching in Physical Education, 23, 318-337.

Utdanningsdirektoratet (2006). Lcereplan $i$ kroppsøving. Hentet fra http://data.udir.no/k106/KRO1-04.pdf

Utdanningsdirektoratet (2012). Lceplan $i$ kroppsøving. Hentet fra http://www.udir.no/k106/KRO1-04/Hele/ Kompetansemaal/kompetansemal-etter-10.-arssteget

Utdanningsdirektoratet (2015). Lcereplan i kroppsøving. Hentet fra http://www.udir.no/k106/KRO1-04/Hele/ Kompetansemaal/kompetansemal-etter-10.-arssteget

Webb, L., Quennerstedt, M., \& Öhman, M. (2008). Healthy bodies: Construction of the body and health in physical education. Sport, Education and Society, 13(4), 353-372.

World health organisation (WHO). (1946). Constitution of the world health organisation. Hentet fra 30.07.2019 fra http://apps.who.int/gb/bd/PDF/bd47/EN/constitution-en.pdf?ua=1 